\title{
Antimicrobial and antioxidant activity of Evernia prunastri extracts and their isolates
}

\author{
A. Shcherbakova ${ }^{1,2,6} \cdot$ A. A. Strömstedt ${ }^{2} \cdot$ U. Göransson ${ }^{2} \cdot$ O. Gnezdilov ${ }^{3} \cdot$ A. Turanov ${ }^{3} \cdot$ D. Boldbaatar ${ }^{2,4} \cdot$ D. Kochkin ${ }^{5}$. \\ G. Ulrich-Merzenich ${ }^{6} \cdot$ A. Koptina ${ }^{2}$ (D)
}

Received: 15 April 2021 / Accepted: 23 June 2021 / Published online: 7 July 2021

(c) The Author(s) 2021

\begin{abstract}
Lichens are symbiotic organisms formed by a fungus and one or more photosynthetic partners which are usually alga or cyanobacterium. Their diverse and scarcely studied metabolites facilitate adaptability to extreme living conditions. We investigated Evernia prunastri (L.) Ach., a widely distributed lichen, for its antimicrobial and antioxidant potential. E. prunastri was sequentially extracted by hexane (Hex), dichloromethane (DCM) and acetonitrile (ACN) that were screened for their antioxidant and antimicrobial (against Staphylococcus aureus, Pseudomonas aeruginosa, Escherichia coli and Candida albicans) activities. The Hex extract possessed the highest antioxidant capacity ( $87 \mathrm{mg}$ ascorbic acid/g extract) corresponding to the highest content of phenols ( $73 \mathrm{mg}$ gallic acid/g extract). The DCM and Hex extracts were both active against $S$. aureus (MICs of 4 and $21 \mu \mathrm{g} / \mathrm{ml}$, respectively) but were less active against Gram-negative bacteria and yeast. The ACN extract exhibited activity on both S. aureus (MIC $14 \mu \mathrm{g} / \mathrm{ml}$ ) and C. albicans (MIC $38 \mu \mathrm{g} / \mathrm{ml}$ ) and was therefore further fractionated by silica gel column chromatography. The active compound of the most potent fraction was subsequently characterized by ${ }^{1} \mathrm{H}$ and ${ }^{13} \mathrm{C}-\mathrm{NMR}$ spectroscopy and identified as evernic acid. Structural similarity analyses were performed between compounds from E. prunastri and known antibiotics from different classes. The structural similarity was not present. Antioxidant and antimicrobial activities of E. prunastri extracts originate from multiple chemical compounds; besides usnic acid, most notably evernic acid and derivatives thereof. Evernic acid and its derivatives represent possible candidates for a new class of antibiotics.
\end{abstract}

G. Ulrich-Merzenich and A. Koptina contributed equally to this work.

A. Koptina

avkoptina@gmail.com

1 Volga State University of Technology, Lenin Sq., 3, Yoshkar-Ola, Russia 424000

2 Pharmacognosy, Department of Pharmaceutical Biosciences, Uppsala University, 75124 Uppsala, Sweden

3 FRC Kazan Scientific Center, Zavoisky Physical-Technical Institute, Russian Academy of Sciences, Sibirsky Tract, 10/7, Kazan, Russia 420029

4 The Liver Center, Dalai Tower, Unesco Street 31, Sukhbaatar District, Ulaanbaatar 14230, Mongolia

5 Faculty of Biology, Lomonosov Moscow State University, GSP-1, 1-12 Leninskiye Gory, Moscow, Russia 119234

6 Medical Clinic III, AG Synergy Research and Experimental Medicine, University Hospital Bonn, Venusberg-Campus 1, 53127 Bonn, Germany 


\section{Graphic abstract}
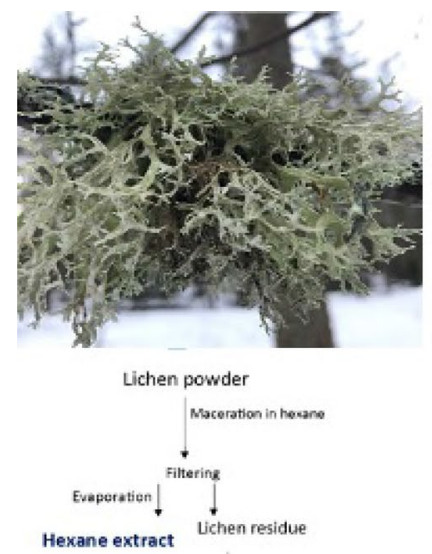

Hexane extract Lichen residue

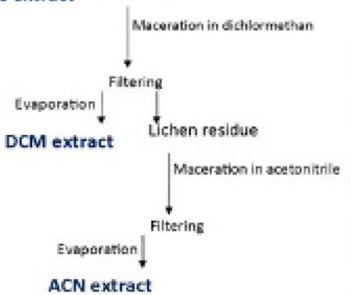

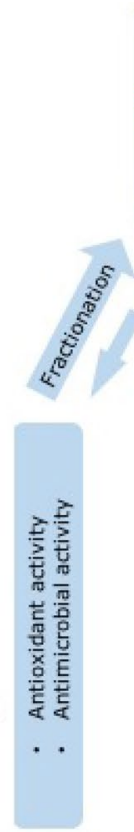
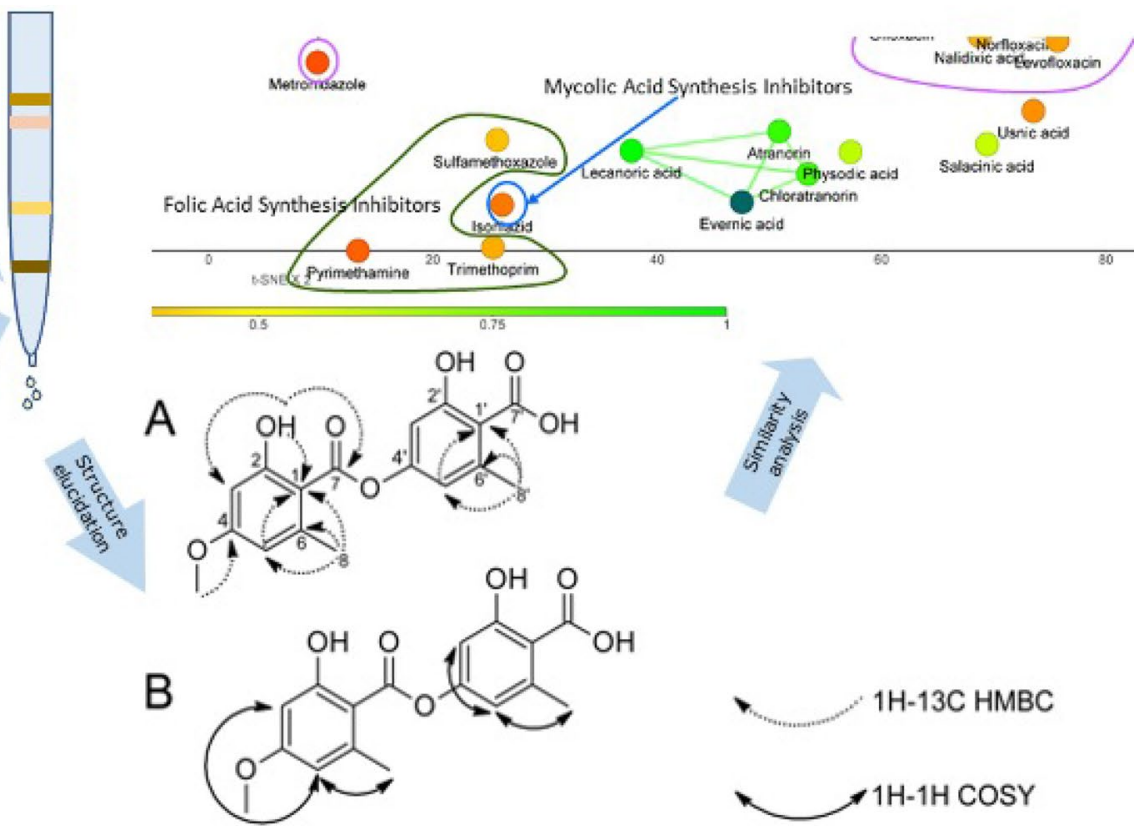

A

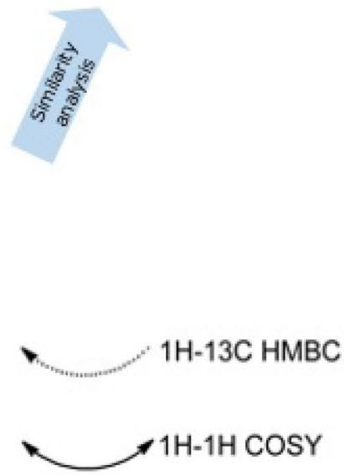

Keywords Antimicrobial activity · Anti-oxidative activity $\cdot$ Evernia prunastri (L.) Ach. · Evernic acid · Lichen · Usnic acid

\section{Introduction}

Antibiotic resistance is one of the biggest threats to global health and development today that is not counterbalanced by the development of new therapeutic agents: no new classes of antibiotics have been developed since 1987 (WHO 2020; Durand et al. 2019; Hutchings et al. 2019). New resistance mechanisms are emerging and spreading globally, threatening our ability to treat common infectious diseases (WHO 2020). Considering that the most clinically relevant classes of antibiotics are derived from natural products (Hutchings et al. 2019), we identified lichens as a potential source of new antimicrobial compounds.

Lichens are organisms consisting of a fungus and a photosynthetic partner (cyanobacteria or algae) in a symbiotic relationship (Calcott et al. 2018). This unique symbiosis generates diverse and proprietary biochemical compositions of lichen compounds which offer a vast potential for the discovery of novel classes of antimicrobial substances (Mitrovic et al. 2011; Zambare and Christopher 2012). For example, depsides, depsidones and usnic acid derivatives are so far uniquely found in lichens (Stocker-Wörgötter et al. 2013).

In vitro studies suggest that lichen extracts may have a broad spectrum of activity against Gram-positive and -negative bacteria, fungi, and protozoan parasites (e.g., Schistosoma mansoni, Leishmania spp., Toxoplasma gondii,
Plasmodium berghei, Trypanosoma cruzi) as well as antiviral activity (Schmeda-Hirschmann et al. 2008; Fritis et al. 2013; Lauinger et al. 2013; Luz et al. 2015; Ranković and Kosanić 2015; Si et al. 2016; Pastrana-Mena et al. 2016; Calcott et al. 2018; Araújo et al. 2019). Additionally to a

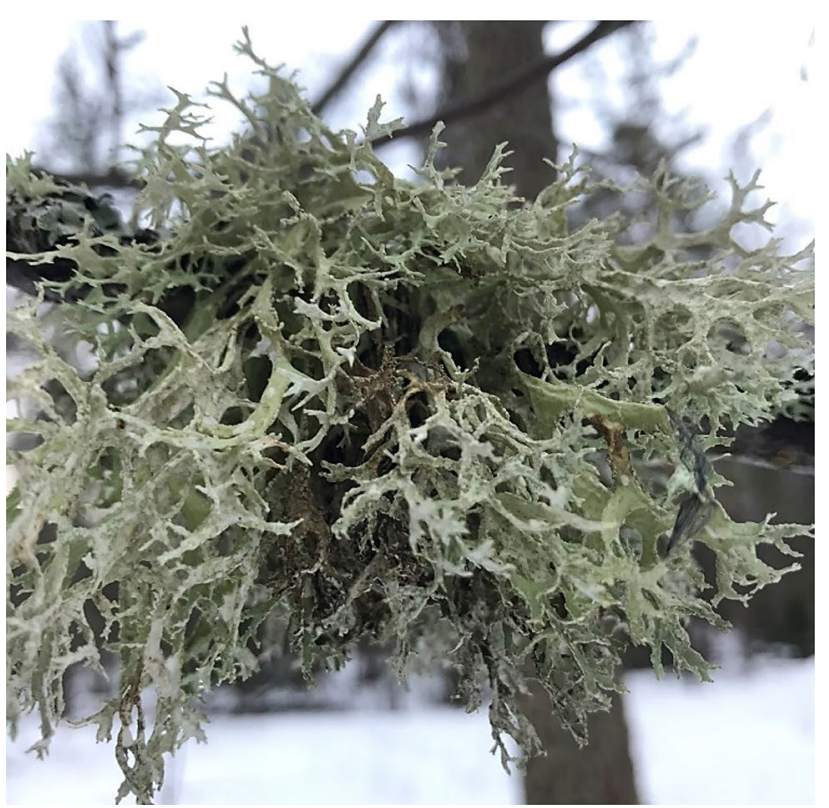

Fig. 1 The lichen Evernia prunastri (L.) Ach. 
prominent antimicrobial activity, lichen compounds were shown to possess analgesic, anticoagulant, anti-inflammatory, antipyretic, antiproliferative, wound healing, sun protecting (against UV irradiation) (Kohlhardt-Floehr et al. 2010; Nguyen 2013), and high antioxidative properties (Crawford 2015; Ranković and Kosanić 2015).

The present study focuses on the evaluation of antimicrobial and antioxidative activities of the lichen Evernia prunastri (L.) Ach., genus Evernia.

Evernia prunastri is widely distributed across the Northern Hemisphere including Europe, North America and Asia. The thallus of E. prunastri (see Fig. 1) is on the upper side yellow-greenish, pale greenish, pale grey-green, with a cortex, on the underside predominantly whitish and somewhat channelled, without cortex, shrub-like, with granular-mealy soralia on the upper side and the margins, almost never with apothecium (disks usually pale yellowish, pale greenish or beige), without cylindrical isidia, usually up to $5 \mathrm{~cm}$ long. Lobes are 1-3 mm wide (Wirth and Anderegg 1995). It grows on deciduous trees, especially oaks and other broadleaf trees, or shrubs (only occasionally on conifers in areas with high humidity) (Golubkova et al. 1996).

The medicinal use of E. prunastri was already known in ancient Greece where it was used as a decoction or ointment for the treatment of diseases of the "womb", against fatigue and as an astringent (Crawford 2015). In the European early modern era, it was used to treat intestinal weakness, fever and pulmonary afflictions (Crawford 2015). However, the form of preparation is unknown.

So far over 70 different metabolites have been identified and characterized in E. prunastri (Joulain and Tabacchi 2009). The most studied compounds are usnic and evernic acids, atranorin (Golubkova et al. 1996; Joulain and Tabacchi 2009; Staples et al. 2020), chloroatranorin (Avalos and Vicente 1987; Staples et al. 2020), atranol and chlorobutanol (Joulain and Tabacchi 2009; Uter et al. 2013; Mowitz et al. 2013; Andersen et al. 2015).

Especially usnic acid is known for its broad-spectrum antimicrobial activity. It is described to possess antibacterial properties against many Gram-positive bacteria (e.g., Streptococcus spp., Pneumococcus spp., Bacillus spp., Enterococcus spp., Staphylococcus aureus (including methicillin resistant), Listeria monocytogenes) (Garcia Rowe et al. 1999; Vijayakumar et al. 2000; Behera et al. 2005; Wang et al. 2006), some Gram-negative bacteria (e.g., Proteus vulgaris, Salmonella typhimurium) (Y1lmaz et al. 2004), and mycobacteria Mycobacterium tuberculosis (at MIC of $32 \mu \mathrm{g} / \mathrm{ml}$ ) (Ingólfsdóttir 2002). Usnic acid is also described as an antifungal (e.g. Candida spp.) (Proksa et al. 1996; Pires et al. 2012; Nithyanand et al. 2015), antiprotozoal (e.g. Leishmania ssp., Trypanosoma cruzi, Trichomonas vaginalis, liver stage parasites of Plasmodium berghei) (Fournet et al. 1997; De Carvalho et al. 2005; Lauinger et al. 2013; Pastrana-Mena et al. 2016; Derici et al.
2018) and antiviral (e.g. human papilloma virus) (Piorkowski 1957; Yamamoto et al. 1995; Sokolov et al. 2012) agent. The sodium salt of usnic acid had been used as an antibiotic (under trade name Binan and Usno) against Gram-positive bacteria and mycobacteria in the USSR since 1955 (Belodubrovskaya et al. 2004). Furthermore, usnic acid can be found in various oral dietary supplements including Lipokinetix ${ }^{\circledR}$ marketed as a weight loss agent but that is now withdrawn due to the fulminant hepatotoxicity and acute liver failure (Han et al. 2004; Pramyothin et al. 2004; Neff et al. 2004; Arneborn et al. 2005; Hsu et al. 2005). Interestingly, there is a claim that in a clinical study to treat Mycobacterium tuberculosis, 30 patients received usnic acid tablets $(90 \mathrm{mg} / \mathrm{day}$ or $1.5 \mathrm{mg} /$ $\mathrm{kg} / \mathrm{day}$ ) for about 71 days, and in another study for bronchitis, 91 patients were treated with $30 \mathrm{mg}$ usnic acid tablets/ day. 10 days were found to be the appropriate therapy period (Luzina and Salakhutdinov 2018).

Evernic acid has been studied much less than usnic acid and is described to have antibacterial activity against, for example, Bacillus mycoides, B. subtilis, Klebsiella pneumoniae and Candida albicans at MIC $0.25 \mathrm{mg} / \mathrm{ml}$, against Escherichia coli at MIC $0.5 \mathrm{mg} / \mathrm{ml}$ and against Aspergillus flavus, A. fumigatus, Penicillium purpurescens and $P$. verrucosum at MIC $1 \mathrm{mg} / \mathrm{ml}$ (Kosanić et al., 2013) as well as against Pseudomonas aeruginosa quorum-sensing systems (Gökalsin and Sesal 2016). Some studies also suggest its effectiveness against $S$. aureus which could, however, not be confirmed in another study (Lauinger et al. 2013). Also, evernic acid is shown to have moderate activity on the Epstein-Barr virus activation inhibition (Yamamoto et al. 1995). Atranorin, among other compounds, has also been described to possess antibacterial and antiprotozoal activity (Araújo et al. 2015; Studzinska-Sroka et al. 2017).

Some lichen compounds (e.g., usnic acid, evernic acid, atranorin, fumarprotocetraric acid, lecanoric acid, diffractaic acid, lobaric acid, stictic acid, salazinic acid, physodic acid, psoromic acid, norstictic acid, protocetraric acid) are described to possess antioxidant properties (White et al. 2014; Araújo et al. 2015; Fernández-Moriano et al. 2017; Studzinska-Sroka et al. 2017).

In the current work, we investigated the antimicrobial and antioxidative properties of different extracts from the lichen Evernia prunastri (L.) Ach. and subsequently performed a bioassay-guided fractionation of the most active extract in order to isolate the active antimicrobial compound(s).

\section{Materials and methods}

\section{Materials}

Lichen samples of Evernia prunastri (L.) Ach. were collected in the Mari El Republic of the Russian Federation 
in June 2012. The lichen was identified by lichenologist G.A. Bogdanov of the Bolshaya Kokshaga Natural Reserve. The voucher specimen of the lichen was deposited at the Department of Forestry and Ecology, Volga State University of Technology, Yoshkar-Ola, Russia.

Antimicrobial assays were conducted using four clinical strains of human pathogens: Escherichia coli ATCC 25922, Staphylococcus aureus ATCC 29213, Pseudomonas aeruginosa ATCC 27853 and the yeast Candida albicans ATCC 90028. Tryptic Soy Broth (TSB) for S. aureus, P. aeruginosa and $C$. albicans cultivation and Luria Broth medium (LB) (Merck KGaA, Darmstadt, Germany) for $E$. coli cultivation were used.

\section{Sample preparation}

\section{Extraction}

Air-dried powdered thalli of the lichens were extracted by sequential maceration with hexane, dichloromethane (DCM) and $60 \%$ acetonitrile in water ( $\mathrm{ACN})$ at room temperature for $24 \mathrm{~h}$ with each solvent. The extracts were filtered and then concentrated under reduced pressure in a rotary evaporator Rotavapor R (Buchi Labortechnik AG, Flawil, Switzerland). The dry extracts were stored at room temperature until usage.

\section{Fractionation and isolation of chemical constituents}

Chemical constituents of $60 \%$ ACN extract of E. prunastri were separated by silica gel column chromatography. The glass column with inner diameter of $40 \mathrm{~mm}$ was packed with silica gel 60 (Merck, Darmstadt, Germany). Four eluents were used sequentially: (1) cyclohexane: acetone (7:4, v/v); (2) cyclohexane: acetone: methanol (7:4:1, v/v/v); (3) cyclohexane: acetone: methanol $(7: 4: 2, \mathrm{v} / \mathrm{v} / \mathrm{v})$; (4) methanol.

In total 91 fractions with volume of $8 \mathrm{ml}$ each at flow rate of $15 \mathrm{ml} / \mathrm{min}$ were collected. Based on TLC analysis fractions containing identical compounds were combined. Batch 85 and $86-89$ were further separated by semi-preparative and preparative RP-HPLC.

TLC was carried out on Silica gel 60 F254 0.25 mm Aluminium plates (Merck, Darmstadt, Germany). Solvent system cyclohexane: acetone: methanol (7:4:2, v/v/v) was used. Zones were visualized under UV light and by dipping into a vanillin-sulfuric acid reagent followed by heating at $120^{\circ} \mathrm{C}$.

Preparative and semi-preparative HPLC was conducted on Äkta Basic 10 HPLC system (Amersham Pharmacia Biotech, Sweden) with $\mathrm{C} 18$ columns. The flow rate was set to 10 and $4 \mathrm{ml} / \mathrm{min}$ and the UV-900 detector was operated at wavelengths of 215,254 and $280 \mathrm{~nm}$. The mobile phases consisted of $10 \%$ (A) and $60 \%$ (B) aqueous acetonitrile, both containing $0.05 \%$ trifluoroacetic acid. The gradient was set to $10-100 \%$ (B) over $21 \mathrm{~min}$.

\section{Characterization and identification of compounds}

${ }^{1} \mathrm{H}$ and ${ }^{13} \mathrm{C}$ NMR spectra were recorded on a "Bruker AVANCE 400" of the Centre of Collective Facilities, FRC Kazan Scientific Centre, at operating frequencies of 400.13 and $100.62 \mathrm{MHz}$, respectively. Chemical shifts were measured with reference to the residual protons of the solvent $\left(\mathrm{CDCl}_{3},{ }^{1} \mathrm{H}, 7.26 \mathrm{ppm},{ }^{13} \mathrm{C}, 77.16 \mathrm{ppm}\right)$.

\section{Antioxidant activity}

\section{Total antioxidant capacity}

The total antioxidant activity of the studied extracts was evaluated by the phosphomolybdenum method as described by Manojlovich et al. (2012). Briefly, $0.2 \mathrm{ml}$ of sample extract was combined with $3 \mathrm{ml}$ of reagent solution $(0.6 \mathrm{M}$ sulfuric acid, $28 \mathrm{mM}$ sodium phosphate and $4 \mathrm{mM}$ ammonium molybdate). The tubes containing the reaction solution were incubated at $95{ }^{\circ} \mathrm{C}$ for $90 \mathrm{~min}$. Then the absorbance of the solution was measured at $695 \mathrm{~nm}$ using a spectrophotometer against blank after cooling to room temperature. Methanol $(0.3 \mathrm{ml})$ was used as the blank. Ascorbic acid (AA) was used as a standard and the total antioxidant capacity is expressed as milligrams of ascorbic acid per gram of the dry extract.

\section{Total phenolic compounds}

The total phenolic content was determined using the Folin-Ciocalteau (FC) method (Manojlovic et al. 2012). Shortly, extracts were diluted to the concentration of $1 \mathrm{mg} /$ $\mathrm{ml}$ and aliquots of $0.5 \mathrm{ml}$ were mixed with $2.5 \mathrm{ml}$ of FC reagent (previously diluted ten-fold with distilled water) and $2 \mathrm{ml}$ of $\mathrm{NaHCO}_{3}(7.5 \%)$. After $15 \mathrm{~min}$ of staying at $45^{\circ} \mathrm{C}$, the absorbance was measured at $765 \mathrm{~nm}$ on a spectrophotometer versus a blank sample. Total phenols were determined as gallic acid equivalents (mg GA/g extract), and the values are presented as means of triplicate analyses.

\section{Antimicrobial activity}

\section{Broth microdilution assay to measure minimal inhibitory concentration (MIC)}

The Minimal Inhibitory Concentration (MIC) was determined for the extracts and fractions by a broth microdilution method previously described (Wiegand et al. 2008). 
Table 1 Antimicrobial activity of different extracts of the lichen E. prunastri and usnic acid

\begin{tabular}{lcccc}
\hline Samples & \multicolumn{4}{l}{ Minimum inhibitory concentration $(\mathrm{MIC}), \mu \mathrm{g} / \mathrm{ml}^{\ddagger}$} \\
\cline { 2 - 5 } & $\begin{array}{l}\text { Staphylococcus } \\
\text { aureus }\end{array}$ & $\begin{array}{l}\text { Pseudomonas } \\
\text { aeruginosa }\end{array}$ & Escherichia coli & Candida albicans \\
\hline $\begin{array}{l}\text { E. prunastri (Hexane) } \\
\begin{array}{l}\text { E. prunastri } \\
\text { (DCM) }\end{array}\end{array} 2^{\left(1 \pm 9^{(0.9)}\right.}$ & $150 \pm 41^{(0.8)}$ & $>500$ & $150 \pm 50^{(0.2)}$ \\
$\begin{array}{l}\text { E. prunastri } \\
(60 \% \text { ACN) }\end{array}$ & $4 \pm 1^{*}$ & $167 \pm 33^{(0.5)}$ & $500 \pm 1^{*}$ & $150 \pm 50^{(0.2)}$ \\
Usnic acid & $14 \pm 3^{(0.1)}$ & $133 \pm 33^{(1.0)}$ & $250 \pm 1^{(0.3)}$ & $38 \pm 13^{*}$ \\
\hline
\end{tabular}

${ }^{\ddagger}$ Data expressed as a mean \pm SD $(n=3$ for each experiment)

$* \mathrm{p}<0.01$ vs. usnic acid
Shortly, bacteria grown overnight in 3\% TSB were rinsed with Tris buffer and diluted in refined LB to obtain a concentration of approximately $10^{6} \mathrm{CFU}$ per $\mathrm{ml}$ as determined by OD600. The fractions were dissolved in 5\% DMSO and a concentration range from 0.1 to $500 \mu \mathrm{g} / \mathrm{ml}$ was tested in a 96 well microplate. Ninety (90) $\mu \mathrm{l}$ of the bacterial suspension was administered into each well. The microplate was incubated at $37{ }^{\circ} \mathrm{C}$ for $6 \mathrm{~h}$ with E. coli, $8 \mathrm{~h}$ with $P$. aeruginosa, $9 \mathrm{~h}$ with $S$. aureus, $12 \mathrm{~h}$ with $C$. albicans. The incubation times for the different strains were chosen according to growth rate rendering approximate similarity in total mass, i.e., pellets of $2 \mathrm{~mm}$ in diameter (Strömstedt et al. 2017). The effects of all extracts were compared with the effect of usnic acid (the most studied antibiotic compound in lichens). Effects of the 5\% DMSO solvent alone was also examined.

Experiments were performed at least in three separate replicates and were found to be consistent within each dilution factor. The MIC was taken as the concentration at which no visible pellet was observed.

\section{Computing the activities of the compounds from $E$. prunastri}

\section{Similarity/activity Cliffs analysis}

Compounds of the E. prunastri extract (Staples et al. 2020) were structurally compared with main drugs of different antibiotics classes. The comparative study and visualization were performed using the DataWarrior software (5.2.1) (Sander et al. 2015). The Analyse Similarity/Activity Cliffs tool was applied to calculate and plot similarity (Guha and Van Drie 2008). Additionally, to visualize the chemical space of molecules, t-SNE (Stochastic Neighbour Embedding) visualization was performed (Van Der Maaten 2014; Karlov et al. 2019). This was followed by a synchronization of the similarity plot with t-SNE.
Similarity score of usnic acid and evernic acid in comparison to the antibiotics was calculated in DataWarrior software based on the comparison of descriptors-FragFp (Sander et al. 2015).

\section{Prediction of toxicity risks}

Prediction of four toxicity risks (Mutagenic, Tumorigenic, Reproductive Effective and Irritant) were estimated in the DataWarrior software (5.2.1) using the 'Calculate properties' tool (Sander et al. 2015). The analyses are based on fragment-based toxicity estimations compiled in the Registry of Toxic Effect of Chemical Substances database and the World Drug Index database (von Korff and Sander 2006).

\section{Statistical analyses}

Statistical analyses were performed using Excel and Origin software packages. To determine the statistical significance of the antioxidant activity student's t-test was utilized. All values are expressed as mean $\pm \mathrm{SD}$ of three parallel measurements.

\section{Results}

\section{Preparation of extracts and fractionation}

The hexane, DCM and ACN macerations of the Evernia prunastri lichen yielded $137 \mathrm{mg}$ ( $2.73 \%$ of sample dry weight), $190 \mathrm{mg}$ (3.80\% of sample dry weight) and $311 \mathrm{mg}(6.22 \%$ of sample dry weight) of extracts, respectively.

The $60 \% \mathrm{ACN}$ fraction was further fractionated to investigate subfractions and isolate and elucidate single active compounds. In total 91 fractions of the ACN extract of $E$. prunastri were collected. Based on the TLC analyses, fractions containing identical compounds were combined which resulted in 15 different solutions that were further used for the MIC assays. 


\section{Antimicrobial activity}

The inhibitory activity of different extracts of E. prunastri as well as of the fractions of the ACN extract was evaluated against clinical strains of four human pathogens, i.e., Grampositive bacterium Staphylococcus aureus, Gram-negative bacteria Pseudomonas aeruginosa and Escherichia coli, and the fungus Candida albicans. Usnic acid, the lichen metabolite known for its antimicrobial properties, was used as a reference. The obtained results are presented in Tables 1 and 2 .

Usnic acid was active against $S$. aureus, with a minimum inhibitory concentration (MIC) of $21 \mu \mathrm{g} / \mathrm{ml}$. A high and significant effect was found for the E. prunastri DCM extract with a MIC of $4 \mu \mathrm{g} / \mathrm{ml}$. For the E. prunastri Hexane extract, the ability to inhibit $S$. aureus was similar to the one of usnic acid. The E. prunastri ACN extract showed a MIC of $14 \mu \mathrm{g} /$ $\mathrm{ml}$, a slightly higher potency than usnic acid.

Against $P$. aeruginosa, the effect of usnic acid was comparable to the E. prunastri extracts and the measured MIC value of $133 \mu \mathrm{g} / \mathrm{ml}$. Our estimated MIC values for the $E$. prunastri ACN, Hexane and DCM extracts (MIC values of 133,150 and $167 \mu \mathrm{g} / \mathrm{ml}$, respectively) were in the range with the one of usnic acid.

Against the Gram-negative bacteria E. coli, usnic acid was not effective (MIC value of $225 \mu \mathrm{g} / \mathrm{ml}$ ). The MIC values of the E. prunastri ACN extract $(250 \mu \mathrm{g} / \mathrm{ml})$ was comparable to the one of usnic acid. The other two E. prunastri extracts showed even higher MIC values (Table 1).

Against $C$. albicans, the highest activity was seen with the E. prunastri ACN extract with a MIC value of $38 \mu \mathrm{g} /$ $\mathrm{ml}$. The effect of the extract is significantly higher than the effect of usnic acid with a MIC of $100 \mu \mathrm{g} / \mathrm{ml}$. The E. prunastri Hexane and DCM extracts showed a low activity with a MIC of $150 \mu \mathrm{g} / \mathrm{ml}$.

The E. prunastri ACN extract showed antimicrobial activity against all tested microorganisms and was therefore fractionated using column chromatography and HPLC into 15 fractions (Supplementary Figure S1) as described in the method section. The individual fractions were subsequently tested for their antimicrobial activity and the resulting MIC values are shown in Table 2.

Fractions V and VI showed high activities against all tested microorganisms. Comparably high activities were also seen for the fractions VII and VIII, but only against $S$. aureus and C. albicans. A reason for such similarity in antimicrobial activity may be explained by the crosspresence of one or more compound(s) in the neighbouring fractions.

Fraction VIII showed the highest activity against $S$. aureus with a MIC value of $2 \mu \mathrm{g} / \mathrm{ml}$. Fraction VI had a slightly lower effect with a MIC of $4 \mu \mathrm{g} / \mathrm{ml}$. This MIC is, however, still lower than the one of usnic acid $(21 \mu \mathrm{g} / \mathrm{ml})$ measured by the same method.

The activities of these fractions against Gram-negative bacteria are quite similar. The MIC values of fractions $\mathrm{V}$ and VI against $P$. aeruginos $a$ were similar and significantly lower than the MIC value of usnic acid (p-value $=0.02$ ). The activity of fraction $\mathrm{V}$ against $E$. coli is similar to the activity of this fraction against $P$. aeruginosa. In contrast, fraction $\mathrm{VI}$ is less effective against $E$. coli.
Table 2 Minimum inhibitory concentration (MIC) of fractions (see Supplementary Figure S1) obtained from acetonitrile: water (3:2) extract of Evernia prunastri

\begin{tabular}{llllll}
\hline Fraction & Yield $(\mathrm{mg})$ & \multicolumn{2}{l}{ MIC $\mu \mathrm{g} / \mathrm{ml}$} & & \\
\cline { 3 - 5 } & & $\begin{array}{l}\text { Staphylococcus } \\
\text { aureus }\end{array}$ & $\begin{array}{l}\text { Pseudomonas } \\
\text { aeruginosa }\end{array}$ & Escherichia coli & Candida albicans \\
\hline I & 5 & $>500$ & $>500$ & 250 & 500 \\
II & 3.4 & $>500$ & $>500$ & $>500$ & $>500$ \\
III & 12.4 & 62.5 & $>500$ & $>500$ & $>500$ \\
IV & 10.7 & $>500$ & $>500$ & 500 & $>500$ \\
V & 10.6 & $\mathbf{1 . 9 5}$ & $\mathbf{3 1 . 2 5}$ & $\mathbf{3 1 . 2 5}$ & 62.5 \\
VI & 31.8 & $\mathbf{0 . 9 8}$ & $\mathbf{3 1 . 2 5}$ & $\mathbf{1 2 5}$ & 62.5 \\
VII & 31.1 & $\mathbf{1 . 9 5}$ & $>500$ & $>500$ & $\mathbf{3 1 . 2 5}$ \\
VIII & 44.9 & $\mathbf{0 . 4 9}$ & $>500$ & $>500$ & 62.5 \\
IX & 12.6 & 3.91 & $>500$ & $>500$ & 125 \\
X & $13.0 *$ & $>500$ & 125 & 500 & $>500$ \\
XI & & 500 & 125 & 500 & $>500$ \\
XII & & 500 & 500 & $>500$ & $>500$ \\
XIII & & 125 & 500 & $>500$ & $>500$ \\
XIV & 11.8 & 15.63 & $>500$ & $>500$ & 500 \\
XV & 224.6 & 125 & 125 & 500 & 500 \\
\hline
\end{tabular}

*Fraction after \#IX (with mass $13 \mathrm{mg}$ ) was further separated using RP-HPLC into 4 more fractions Numbers in bold indicate susceptibility or intermediate antibacterial activity 
The effects of the fractions V, VI and VIII against $C$. albicans are the same and the effect of fraction VII is insignificantly higher $(p$-value $=0.34)$. All these fractions are more effective than usnic acid ( $\mathrm{p}$-value $<0.05$ ).

In general, the antimicrobial activity of the fractions is higher than the one of the ACN extract itself.

Since the fractions $\mathrm{V}$ and VI inhibited the growth of all tested microorganisms, and, besides that, fraction VI showed a higher effect against $S$. aureus, it was chosen for further characterisation and NMR analysis.

\section{Identification of chemical compounds}

Based on ${ }^{1} \mathrm{H}$ and ${ }^{13} \mathrm{C}$ NMR data, the primary compound of fraction VI was identified as evernic acid. Chemical shifts $(\delta, \mathrm{ppm})$ and coupling constants $(\mathrm{J}, \mathrm{Hz})$ for the extract and evernic acid standard are as follow:

\section{Extract}

${ }^{1} \mathrm{H}$ NMR (CDCl3), $\delta$, ppm (J, Hz): $2.59 \mathrm{~s}(3 \mathrm{H}, 8 \mathrm{CH} 3), 2.76 \mathrm{~s}$ $\left(3 \mathrm{H}, 8^{\prime} \mathrm{CH} 3\right), 3.89 \mathrm{~s}(3 \mathrm{H}, \mathrm{OCH} 3), 6.42 \mathrm{~m}(2 \mathrm{H}, 3 \mathrm{CH}, 5 \mathrm{CH})$, $6.57 \mathrm{~d}\left(1 \mathrm{H}, 5^{\prime} \mathrm{CH} 3, \mathrm{~J} 2.0\right), 6.69 \mathrm{~d}\left(1 \mathrm{H}, 3^{\prime} \mathrm{CH} 3, \mathrm{~J} 2.0\right), 11.08 \mathrm{~s}$ $\left(3 \mathrm{H}, 2 \mathrm{COH}, 2^{\prime} \mathrm{COH}, 7^{\prime} \mathrm{COH}\right)$.

${ }^{13} \mathrm{C}$ NMR (CDCl3), $\delta$, ppm: 24.43, (8C), $24.73\left(8^{\prime} \mathrm{C}\right)$, 55.57 (OCH3), 99.04 (3C), 104.38 (1C), 109.09 (1'C), $109.18\left(3^{\prime} \mathrm{C}\right), 112.11(5 \mathrm{C}), 117.09\left(5^{\prime} \mathrm{C}\right), 143.59$ (6C), $144.96\left(6^{\prime} \mathrm{C}\right), 155.08$ (4'C), 160.09 (2'C), 165.04 (2C), 165.47 (4C), 166.67 (7C), 169.70 ( $\left.7^{\prime} \mathrm{C}\right)$.

\section{Evernic acid}

${ }^{1} \mathrm{H}$ NMR $(\mathrm{CDCl} 3), \delta, \mathrm{ppm}(\mathrm{J}, \mathrm{Hz}): 2.58 \mathrm{~s}(3 \mathrm{H}, 8 \mathrm{CH} 3), 2.70 \mathrm{~s}$ $\left(3 \mathrm{H}, 8^{\prime} \mathrm{CH} 3\right), 3.88 \mathrm{~s}(3 \mathrm{H}, \mathrm{OCH} 3), 6.41 \mathrm{~m}(2 \mathrm{H}, 3 \mathrm{CH}, 5 \mathrm{CH})$, $6.56 \mathrm{~d}\left(1 \mathrm{H}, 5^{\prime} \mathrm{CH} 3, \mathrm{~J} 2.0\right), 6.68 \mathrm{~d}\left(1 \mathrm{H}, 3^{\prime} \mathrm{CH} 3, \mathrm{~J} 2.0\right), 11.04 \mathrm{~s}$ $\left(2 \mathrm{H}, 2 \mathrm{COH}, 2^{\prime} \mathrm{COH}\right), 11.41 \mathrm{~s}\left(1 \mathrm{H}, 7^{\prime} \mathrm{COH}\right)$.

${ }^{13} \mathrm{C}$ NMR (CDCl3), $\delta$, ppm: $24.24(8 \mathrm{C}), 25.83\left(8^{\prime} \mathrm{C}\right)$, 57.42 (OCH3), 98.78 (3C), 105.69 (1C), $109.06\left(1^{\prime} \mathrm{C}\right)$, $109.13\left(3^{\prime} \mathrm{C}\right), 114.58(5 \mathrm{C}), 119.05\left(5^{\prime} \mathrm{C}\right), 143.22(6 \mathrm{C})$, 144.75 (6'C), $155.08\left(4^{\prime} \mathrm{C}\right), 160.24\left(2^{\prime} \mathrm{C}\right), 164.00$ (2C), 165.44 (4C), 166.66 (7C), 169.71 ( $\left.7^{\prime} \mathrm{C}\right)$.

The numbering of carbons is standard for depsides and depsidones, C-7 and C-8 refer to the carbons of the carboxylic acid and the methyl group, respectively (Narui et al. 1998). ${ }^{1} \mathrm{H}-{ }^{13} \mathrm{C}$ HMBC and ${ }^{1} \mathrm{H}-{ }^{1} \mathrm{H}$ COSY correlations were reasonable for the structure (Fig. 2).

The determined molecular formula and the NMR data analysis were compared to published literature data which confirms that the investigated compound is evernic acid ((2-hydroxy-4-[(2-hydroxy-4-methoxy-6-methylbenzoyl) oxy]-6-methylbenzoate) (Huneck and Yoshimura 1996; Narui et al. 1998). To further verify this, the NMR analysis
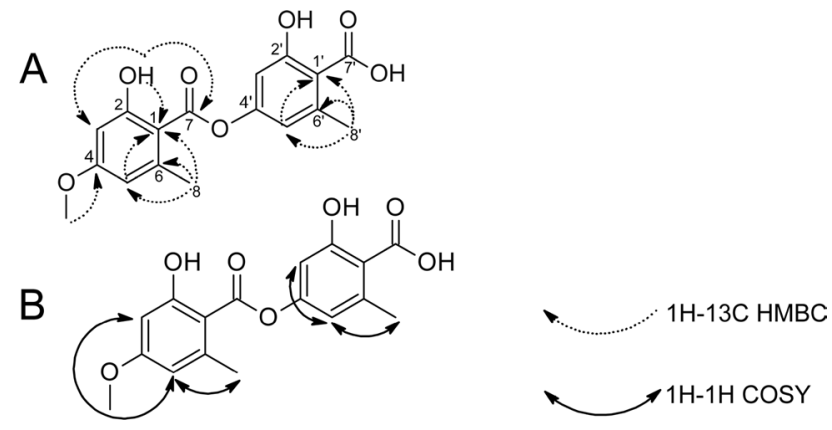

Fig. 2 Structure and key ${ }^{1} \mathrm{H}-{ }^{13} \mathrm{C} \operatorname{HMBC}(\mathbf{A})$ and ${ }^{1} \mathrm{H}-{ }^{1} \mathrm{H}$ COSY (B) correlations of the major compound from the fraction VI

of pure evernic acid was performed and its NMR spectra were compared with the NMR spectra of the ACN extract fraction VI. The spectra were similar enough to identify the primary active compound in the extract as evernic acid.

\section{Hypothetical mechanism of antimicrobial action}

To elucidate further the potential mode of action of evernic acid, we analysed the structural similarity to the known antibiotic classes and its similarity to other lichen compounds. Interestingly evernic acid is structurally different from almost all main classes of antibiotics, with a slight similarity to folic acid synthesis inhibitors (mostly due to the ring system) (Fig. 3). However, evernic acid has a similarity with other lichen compounds as shown in Fig. 3. It is highly similar to lecanoric acid, atranorin and chloratronin, moderately similar to physodic acid and salacinic acid and less similar to usnic acid.

Usnic acid has more similarity to known antibiotics than evernic acid. The highest similarity is with a cell wall synthesis inhibitor - vancomycin $(\mathrm{FragFp}=0.54)$ and RNA synthesis inhibitor - rifampin ( $\mathrm{FragFp}=0.52)$ (Supplementary Figure S2).

Evernic acid is moderately similar to folic acid synthesis inhibitors as sulfamethoxazole (FragFp $=0.38$ ) and trimethoprim $(\mathrm{FragFp}=0.34)($ Supplementary Figure $\mathrm{S} 2)$.

Both evernic acid and usnic acid showed quite identical similarity score to fluoroquinolones. Nalidixic acid and norfloxacin are the most similar compounds to evernic acid with FragFps of 0.34 and 0.33 , respectively. Usnic acid possesses the highest similarity with moxifloxacin $(\mathrm{FragFp}=0.51)$ and gatifloxacin $($ FragFp $=0.50)$.

\section{Possible toxicity of the E. prunastri extracts}

The toxicity risks of the described compounds from $E$. prunastri were predicted using the DataWarrior software (von Korff and Sander 2006; Sander et al. 2015). Results are shown in Table 3. According to the prediction, none 


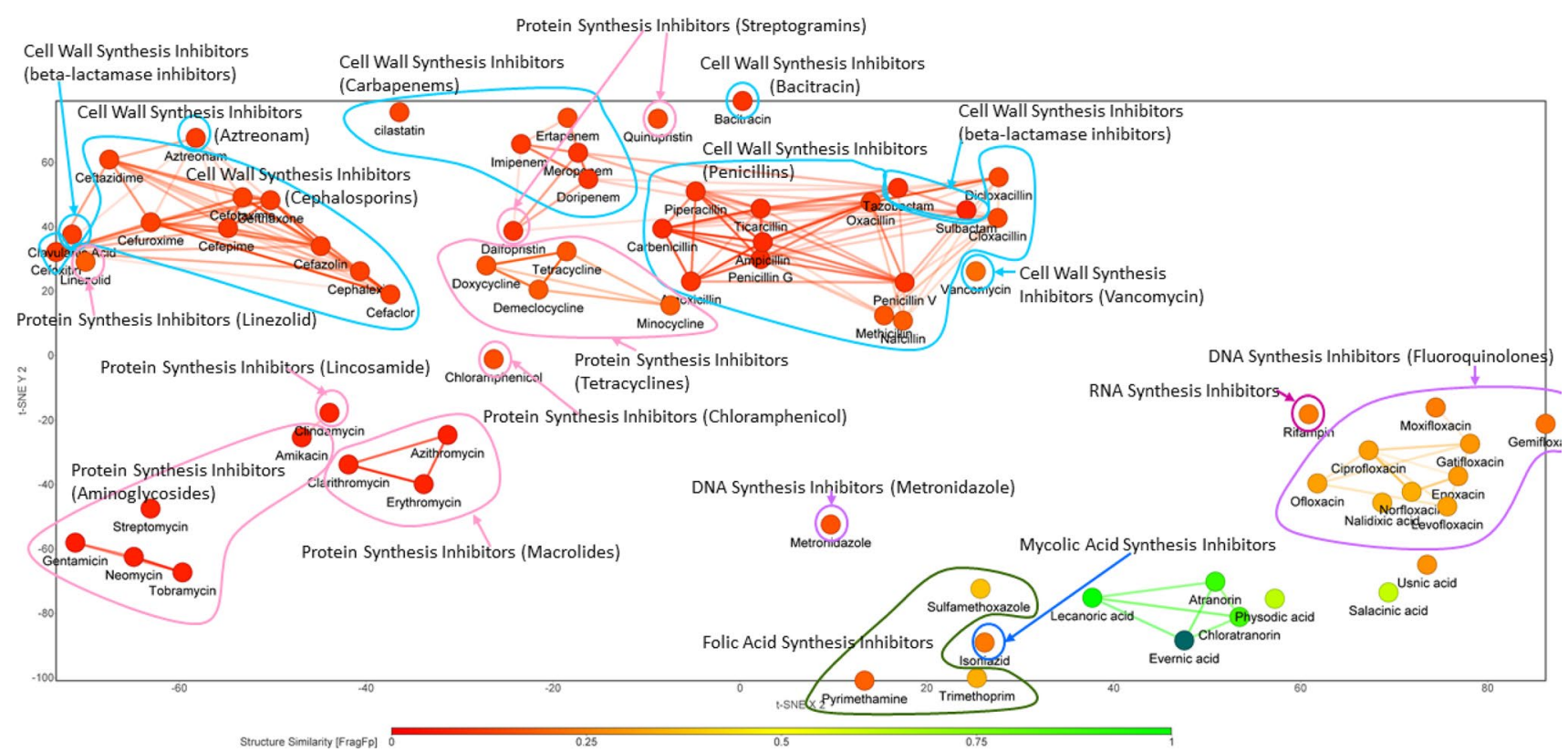

Fig. 3 Similarity Chart of evernic acid vs. known classes of antibiotics with application t-SNE visualization approach. The colours from red to green indicate the range from no structural similarity to $100 \%$ similarity, respectively (Van Der Maaten 2014). The sample disposi-

Table 3 Predicted toxicity risks for E. prunastri constituents based on fragment-based toxicity estimation compilated from Registry of Toxic Effect of Chemical Substances database and World Drug Index database (von Korff and Sander 2006)

\begin{tabular}{lllll}
\hline Name & Mutagenic & Tumorigenic & $\begin{array}{l}\text { Reproduc- } \\
\text { tive effective }\end{array}$ & Irritant \\
\hline Physodic acid & None & None & None & High \\
Chloratranorin & None & None & None & None \\
Salacinic acid & None & None & High & None \\
Atranorin & None & None & None & None \\
Usnic acid & None & None & High & None \\
Evernic acid & None & None & None & None \\
Lecanoric acid & None & None & None & None \\
\hline
\end{tabular}

of the depsides associated with a toxicity risk. However, depsidones and usnic acid present toxicity risks, either as an irritant - physodic acid or through reproductive effects - salacinic acid and usnic acid (Table 3). None of the compounds was predicted to carry mutagenic or tumorigenic risks.

\section{Antioxidative properties of the $E$. prunastri extracts}

In this study, three lichen E. prunastri extracts (Hexane, DCM, ACN) were investigated for their antioxidant potential. tion depends on the similarity and is distributed according to sampling (Karlov et al. 2019). Structurally similar to evernic acid are the lichen compounds lecanoric acid, atranorin, and chloroatranorin (in green) as well as physodic acid, and salacinic acid (light green)

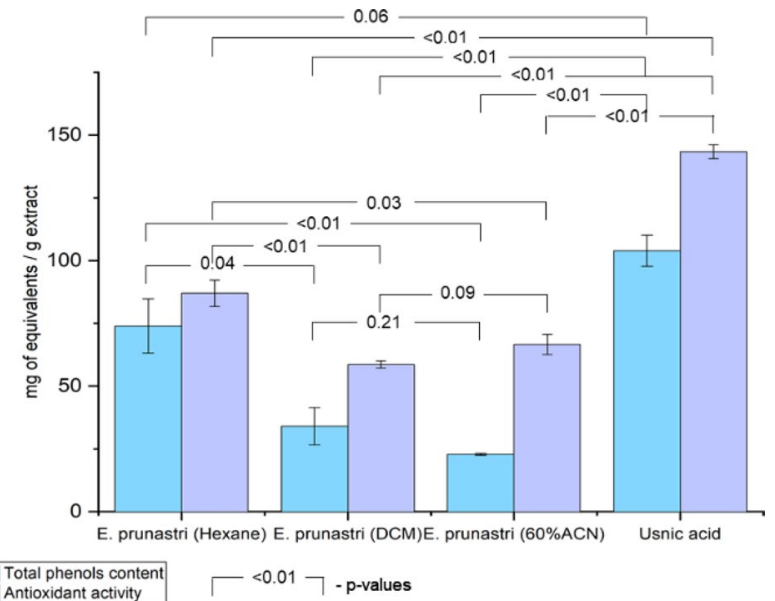

Fig. 4 Antioxidant activity and total phenolic content of the E. prunastri extracts and usnic acid: total phenols, equivalents of gallic acid/g extract; antioxidant activity, mg ascorbic acid/g extract. Data are expressed as a mean $\pm \mathrm{SD}(\mathrm{n}=3$ for each experiment)

The antioxidant activity and the total phenol content of the different $E$. prunastri extracts in comparison to usnic acid are presented in Fig. 4. Usnic acid was used as a reference as it is a well-known lichen compound and is present in E. prunastri.

Usnic acid had shown the highest antioxidant activity (Fig. 4). Among the E. prunastri extracts, the hexane extract showed the highest antioxidant activity equivalent 
to $87 \mathrm{mg}$ ascorbic acid per $1 \mathrm{~g}$ of extract $(\mathrm{p}<0.01$ and $\mathrm{p}=0.03$ vs. DCM and ACN extracts). The ACN and DCM extracts showed significantly lower activity equivalent to 67 and $59 \mathrm{mg}$ ascorbic acid per $1 \mathrm{~g}$ of extract, respectively. These effects largely correspond with the total phenolic content: 74, 34 and $23 \mathrm{mg}$ equivalent of gallic acid per $1 \mathrm{~g}$ of extract for Hexane, DCM and ACN extracts, respectively ( $p=0.04$ and $p<0.01$ Hexane vs. DCM and ACN extracts). The difference between the DCM extract and the ACN extract is not significant $(\mathrm{p}=0.09$ for antioxidant activity and $p=0.21$ for total phenols content). The ability of the extracts to deoxidize correlates directly to their total content of phenols $(\mathrm{r}=0.82)$.

\section{Discussion}

Usnic acid has been reported to be effective against antibiotic-resistant Gram-positive bacteria, e.g. vancomycinresistant enterococci and methicillin-resistant $S$. aureus (MRSA) (Araújo et al. 2015). Interestingly, the inhibitory activity of usnic acid was lower against antibiotic susceptible strains of $S$. aureus and higher against MRSA strains (Tozatti et al. 2016; Victor et al. 2018; Sinha et al. 2019). The MIC values of usnic acid against different clinical isolates of S. aureus vary between 8 and $50 \mu \mathrm{g} / \mathrm{ml}$ (Gupta et al. 2012; Pompilio et al. 2013, 2016; Maciąg-Dorszyńska et al. 2014; Tozatti et al. 2016). In general, our results are corresponding to published ones.

There is less information about the antimicrobial activity of E. prunastri. An acetone extract from E. prunastri has been published to be active against $S$. aureus at the concentration range of $0.078-0.5 \mathrm{mg} / \mathrm{ml}$ and a MRSA clinical isolate at the concentration of $0.039 \mathrm{mg} / \mathrm{ml}$ (Tapalsky et al. 2017; Aoussar et al. 2020). A methanol extract was active at the concentration of $0.156 \mathrm{mg} / \mathrm{ml}$ (Mitrović et al. 2011). Results obtained in this research demonstrated much higher activity. In the case of E. prunastri Hexane extract, the effect on $S$. aureus was similar to the one of usnic acid. This broad MIC range could be due to different experiment setups, such as the number of bacteria used since the higher MIC was observed when a higher number of colony-forming units (CFU) was utilizing than for the lower MIC. The quantity of seeded microorganisms has been argued to thus effect microdilution MIC outcome (Strömstedt et al. 2017).

Against $P$. aeruginosa, usnic acid demonstrated a low antibacterial activity but lay within the broad range of earlier reported for usnic acid MIC values of 5.2 and $256 \mu \mathrm{g} /$ $\mathrm{ml}$ (Francolini et al. 2004; Victor et al. 2018). The 50-fold higher MIC was observed when a 50-times higher number of colony-forming units (CFU) was utilizing than for the lower MIC. Different extracts from E. prunastri have been published to be active against $P$. aeruginosa at concentrations of 2.5-25 mg/ml (Mitrović et al. 2011; Aoussar et al. 2020). Another publication regarding to acetone extract from $E$. prunastri described no effect on $P$. aeruginosa at a concentration below $500 \mu \mathrm{g} / \mathrm{ml}$ (Tapalsky et al. 2017). In our case activity of the extracts against $P$. aeruginosa was comparable to the one of usnic acid, but higher than the published one.

Against another Gram-negative bacteria E. coli, usnic acid is reported to be effective with MIC values ranging from 5.2 to $20 \mu \mathrm{g} / \mathrm{ml}$ (Maciąg-Dorszyńska et al. 2014; Victor et al. 2018) for the different sensitive strains and more than $100 \mu \mathrm{g} / \mathrm{ml}$ for resistant strains of E. coli (Victor et al. 2018). Again, the difference in results is likely due to the different concentrations of bacteria used. In the current study, $10^{6} \mathrm{CFU} / \mathrm{ml}$ was used whereas Victor et al. used a concentration of $10^{4} \mathrm{CFU} / \mathrm{ml}$. Comparing to those, our investigations showed usnic acid as less effective. The activity of the extracts was comparable to one of usnic acid and corresponding to the published results (Tapalsky et al. 2017).

The activity of usnic acid against $C$. albicans was much lower than a reported one with the MIC of $75 \mu \mathrm{g} / \mathrm{ml}$ (Nithyanand et al. 2015). In contrast to this, the extracts showed higher activity than a published one (Tapalsky et al. 2017), but with MIC in the range of usnic acid. The only difference was found for the E. prunastri $\mathrm{ACN}$, which was significantly more active than usnic acid.

Additionally, having a phenolic nature, usnic acid possesses also antioxidant capacities (Araújo et al. 2015). It is known, that phenols have a high antioxidant capacity, mostly due to their reduction ability (Garcia-Mateos 2017). They are able to capture and neutralize free radicals and reactive oxygen species (Wei et al. 2012). Extracts from E. prunastri, in the turn, showed moderate antioxidant activity comparing to usnic acid and a lower number of phenols. Obtained results are corresponding to the published ones (Mitrović et al. 2011; Hawrył et al. 2020; Aoussar et al. 2020).

We demonstrated that $E$. prunastri extracts possess antioxidant and antimicrobial activities. Difference in activities are based on different compound compositions of the extracts and it was identified for the first time in this study that the hexane extract yields the highest antioxidative activity whereas the ACN extract possesses the highest antimicrobial activity against all tested microorganisms. The MIC values of the ACN extract were comparable to usnic acid, i.e., $21,133,225$ and $100 \mu \mathrm{g} / \mathrm{ml}$ against $S$. aureus, P. aeruginosa, E. coli and C. albicans, respectively.

The bioassay-guided fractionation of E. prunastri ACN extract showed that some fractions obtained had higher activity. Especially, fractions V and VII showed activities comparable to published data on usnic acid (Gupta et al. 2012; Pompilio et al. 2013, 2016; Maciąg-Dorszyńska et al. 2014; Tozatti et al. 2016). 
To put obtained results into perspective, the Clinical and Laboratory Standards Institute (CLSI) recommends MIC values from 0.12 to $32 \mu \mathrm{g} / \mathrm{ml}$ as effective concentrations against $S$. aureus for conventional antibiotics depending on the class (CLSI 2018). The European Committee on Antimicrobial Susceptibility Testing (EUCAST) describes the effective concentrations against $S$. aureus in the MIC range from 0.03 to $16 \mu \mathrm{g} / \mathrm{ml}$ for different classes of antibiotics (EUCAST 2019). Thus, in the case of our study $S$. aureus may be considered susceptible to fractions V to X and XIV.

The effect of those fractions on Gram-negative bacteria $P$. aeruginosa and E. coli was low. Both bacteria can be considered resistant to these fractions according to the CLSI and EUCAST recommendations (CLSI 2018; EUCAST 2019).

Against $C$. albicans, fractions V to VIII showed effect better than usnic acid, and, despite this, according to the EUCAST, $C$. albicans is non-susceptible to the tested fractions (EUCAST 2020).

Fraction VI showed the highest inhibitory effects against all tested microorganisms in concentrations usually observed for intermediately potent antibiotics $(4-25 \mu \mathrm{g} / \mathrm{ml})$. In this fraction, the most abundant compound was identified as evernic acid.

The chemical characterization of the total extract of $E$. prunastri earlier (Staples et al. 2020) showed that usnic acid, lecanoric acid and chloroatranorin were among the compounds produced in addition to evernic acid at high concentrations, with evernic acid being the most abundant compound (Staples et al. 2020). Besides chloroatranorin also atranorin was present but in smaller amounts. It may be interesting to note that authors, when comparing E. prunastri lichens from three different geographical regions, could detect two compounds - the depsidones salazinic acid and physodic acid - only in E. prunastri collected in Mari-El, Russian Federation that is used in the current study.

Data on mechanisms of the antimicrobial action of evernic acid are not available. Only data on antibiofilm and antibiofilm maturation activity of an E. prunastri extract against C. albicans (Millot et al. 2017), as well as inhibiting quorum sensing activity against $P$. aeruginosa (Gökalsın and Sesal 2016) has been identified. The mechanism of action against $P$. aeruginosa quorum sensing is based on the inhibition of lasB and rhlA genes expression (Gökalsın and Sesal 2016).

Staples et al. demonstrated earlier that evernic acid is the main constituent of E. prunastri (Staples et al. 2020). Considering our findings and the ones from the biofilm experiments (Gökalsın and Sesal 2016) it can be hypothesized that evernic acid is one of the main constituents responsible for the inhibition of the biofilm formation (especially for P. aeruginosa and $C$. albicans).

However, some mechanisms of antimicrobial activity for usnic acid are described. Against Gram-positive bacteria $S$. aureus, usnic acid can act as a membrane-damaging agent (Gupta et al. 2012). Moreover, investigations on Bacillus subtilis in models of artificial planar bilayer lipid membranes and rat liver mitochondria have demonstrated that a potential mechanism of the antimicrobial capacities of usnic acid can be related to its protonophoric activity (Antonenko et al. 2019). Being lipophilic, usnic acid permeates the bilayer membrane, causing proton leakage, and disrupts the bacterial membrane (Lauinger et al. 2013; Antonenko et al. 2019). Evernic acid, also being lipophilic (ChEMBL, https://www.ebi.ac.uk/chembl/) with a slight structural similarity to usnic acid, may - hypothetically - also be able to compromise bacterial cell membranes and thereby exert antimicrobial activity.

The influence of usnic acid on a prooxidant-antioxidant balance has been described as a mechanism of the anti-candida effect (Peralta et al. 2017). The antioxidant properties of the extract containing evernic acid are significantly lower compared to usnic acid. Thus, the anticandida mechanism of evernic acid is not necessarily related to its antioxidant properties.

Another possible mechanism of usnic acid activity against Mycobacterium tuberculosis, E. coli, S. aureus is the binding to allosteric sites on the FabI (enoyl reductase enzyme) protein surface, which affects enzyme activity (Lauinger et al. 2013). Moreover, this mechanism is described for the activity of usnic acid against the bloodstage Plasmodium falciparum as well as the liver stage $P$. berghei (Lauinger et al. 2013). At the same time, evernic acid inhibited FabI and FabZ of Plasmodium falciparum and FabI of E. coli and S. aureus (Lauinger et al. 2013). Additionally, usnic acid shows activity against other parasites of Leishmania spp. by inducing apoptosis (Derici et al. 2018).

Atranorin has been described to be active against Gramnegative bacteria which is uncommon for other known lichen compounds (Studzinska-Sroka et al. 2017). The presence of atranorin or (and) structural similarity of evernic acid could thus explain the activity against Gram-negative bacteria observed in our experiments.

Also, evernic acid is described to downregulate the expression of the genes lasB (elastase) and rhlA (rhamnolipid production) which are virulence factors in $P$. aeruginosa (Gökalsın and Sesal 2016).

The scaffold of evernic acid is phenyl salicylate (ZINC, http://zinc.docking.org/). Salicylates have been shown to possess antibiofilm and anti-metabolic effects on bacteria (Damman 2013).

Despite usnic acid has been shown to be hepatotoxic (Guo et al. 2008; Luzina and Salakhutdinov 2018) the toxicity of other lichen compounds have been barely investigated to date. With the support of in silico modelling, usnic acid and depsidones were predicted to have toxic risks, corresponding 
to the publications. On the other hand, depsides (a class of evernic acid) were not associated with the toxicity risks.

It is interesting to note, that a whole methanol E. prunastri extract has been screened for its antigenotoxic capacity against several mutagens such as $N$-methyl- $N^{\prime}$-nitro- $N$ nitrosoguanidine, acridin and aflatoxin using WP2, Ames and sister chromatid exchange test systems (Alpsoy et al. 2015). The data obtained have clearly shown that the extract has significant antigenotoxic effects which are thought to be partly due to the antioxidant activities and antioxidant inducing capability (Alpsoy et al. 2015).

Numbers of research describe lichen compounds as potential antibiotics (especially against Gram-positive bacteria) (Shrestha and Clair 2013; Francolini et al. 2019; Sepahvand et al. 2021). To date, the lichen compounds were not ascribed to any antibiotic class. A structural similarity comparison of evernic acid revealed no structural similarity with such antibiotic classes as Cell wall synthesis inhibitors and Protein synthesis inhibitors. Evernic acid and other depsides have structures slightly similar to Folic acid synthesis inhibitors and DNA synthesis inhibitors.

Folate (folic acid) is a designation for cofactors that consist of three moieties: para-aminobenzoic acid (PABA), pterin and glutamates (Bertacine Dias et al. 2018). Tetrahydrofolate (a pterin ring) has an essential role in the biosynthesis of purines, thymidylate, pantothenate, RNA and amino acids (Bertacine Dias et al. 2018). Among folic acid synthesis inhibitors, sulfamethoxazole and trimethoprim were the most similar to evernic acid compounds. Sulfamethoxazole being similar to PABA compete with the latter during synthesis of dihydrofolate (Kemnic and Coleman 2021). Trimethoprim is also a dihydrofolate inhibitor. Alternatively to sulfamethoxazole, it halts the production of tetrahydrofolate, which is necessary for the biosynthesis of bacterial nucleic acids and proteins (Kemnic and Coleman 2021).

DNA synthesis inhibitors (quinolones) block DNA replication apparatus via the binding to the complexes of DNA with DNA topoisomerase IV and DNA gyrase (Hooper and Jacoby 2016). The DNA topoisomerase IV and DNA gyrase catalyse double-strand break followed by duplication of the strands (Hooper and Jacoby 2016). Fluoroquinolones are quinolones substituted with fluorine. Nalidixic acid and norfloxacin are fluoroquinolones are the most similar to evernic acid. Moxifloxacin and gatifloxacin were found the most identical to usnic acid. All described antibiotics act as DNA gyrase inhibitors (Mohammed et al. 2019).

This was also the case for other metabolites of E. prunastri as atranorin, chloratranorin, lecanoric acid and the two depsidones salazinic acid and physodic acid. These compounds are structurally similar to evernic acid and are therefore possible candidates for antibiotics representing a novel class of substances with antimicrobial activity.
Supplementary Information The online version contains supplementary material available at https://doi.org/10.1007/s11274-021-03099-y.

Acknowledgements This work was supported with a grant from the President of the Russian Federation for Young Scientists [Number MK5290.2012.4] and a grant for international mobility from the Volga State University of Technology. The authors thank lichenologist G.A. Bogdanov for his help in the identification of the lichen and Bernd Merzenich for his skilful language editing.

Author contributions All authors contributed to the study conception and design. The work was conceptualized by Anna Koptina, Adam Strömstedt and Ulf Göransson. Material preparation, data collection and analyses were performed by Anastasiia Shcherbakova, Delgebrat Boldbaatar, Alexander Turanov, Oleg Gnezdilov, Dmitry Kochkin. Funds were obtained by Anna Koptina and Anastasia Shcherbakova. Supervision was performed by Anna Koptina and Gudrun UlrichMerzenich. The first draft of the manuscript was written by Anastasiia Shcherbakova, Anna Koptina and Gudrun Ulrich-Merzenich and all authors commented on previous versions of the manuscript. All authors read and approved the final manuscript.

Funding Open access funding provided by Uppsala University. This work was supported with a grant from the President of the Russian Federation for Young Scientists [Number MK5290.2012.4] and a grant for international mobility from the Volga State University of Technology.

Data availability Not applicable.

Code availability Not applicable.

\section{Declarations}

Conflict of interest The authors have no conflicts of interest to declare that are relevant to the content of this article.

Ethical approval Not applicable.

Consent to participate Not applicable.

Consent for publication Not applicable.

Open Access This article is licensed under a Creative Commons Attribution 4.0 International License, which permits use, sharing, adaptation, distribution and reproduction in any medium or format, as long as you give appropriate credit to the original author(s) and the source, provide a link to the Creative Commons licence, and indicate if changes were made. The images or other third party material in this article are included in the article's Creative Commons licence, unless indicated otherwise in a credit line to the material. If material is not included in the article's Creative Commons licence and your intended use is not permitted by statutory regulation or exceeds the permitted use, you will need to obtain permission directly from the copyright holder. To view a copy of this licence, visit http://creativecommons.org/licenses/by/4.0/.

\section{References}

Alpsoy L, Orhan F, Nardemir G et al (2015) Antigenotoxic potencies of a lichen species, Evernia prunastri. Toxicol Ind Health 31:153-161. https://doi.org/10.1177/0748233712469655 
Andersen F, Andersen KH, Bernois A et al (2015) Reduced content of chloroatranol and atranol in oak moss absolute significantly reduces the elicitation potential of this fragrance material. Contact Dermat 72:75-83. https://doi.org/10.1111/cod.12312

Antonenko YN, Khailova LS, Rokitskaya TI et al (2019) Mechanism of action of an old antibiotic revisited: role of calcium ions in protonophoric activity of usnic acid. Biochim Biophys Acta Bioenerg 1860:310-316. https://doi.org/10.1016/j.bbabio.2019.01.005

Aoussar N, Laasri FE, Bourhia M et al (2020) Phytochemical analysis, cytotoxic, antioxidant, and antibacterial activities of lichens. Evid Based Complement Altern Med 2020:8104538. https://doi.org/10. $1155 / 2020 / 8104538$

Araújo AAS, De Melo MGD, Rabelo TK et al (2015) Review of the biological properties and toxicity of usnic acid. Nat Prod Res 29:2167-2180. https://doi.org/10.1080/14786419.2015.1007455

Araújo HDA, Aires AL, Soares CLR et al (2019) Usnic acid potassium salt from Cladonia substellata (Lichen): synthesis, cytotoxicity and in vitro anthelmintic activity and ultrastructural analysis against adult worms of Schistosoma mansoni. Acta Trop 192:110. https://doi.org/10.1016/j.actatropica.2018.12.024

Arneborn P, Jansson A, Böttiger Y (2005) Acute hepatitis in a woman after intake of slimming pills bought via Internet. Lakartidningen 102:2071-2072

Avalos A, Vicente C (1987) The occurrence of lichen phenolics in the photobiont cells of Evernia prunastri. Plant Cell Rep 6:74-76. https://doi.org/10.1007/BF00269744

Behera BC, Verma N, Sonone A, Makhija U (2005) Antioxidant and antibacterial activities of lichen Usnea ghattensis in vitro. Biotechnol Lett 27:991-995. https://doi.org/10.1007/s10529-005-7847-3

Belodubrovskaya GA, Blinova KF, Vandyshev VV et al (2004) Herbal drugs. Pharmacognosy. SpetsLit, Saint-Peterburg

Bertacine Dias MV, Santos JC, Libreros-Zúñiga GA et al (2018) Folate biosynthesis pathway: mechanisms and insights into drug design for infectious diseases. Future Med Chem 10:935-959. https://doi. org/10.4155/fmc-2017-0168

Calcott MJ, Ackerley DF, Knight A et al (2018) Secondary metabolism in the lichen symbiosis. Chem Soc Rev 47:1730-1760. https://doi. org/10.1039/C7CS00431A

CLSI (2018) Performance standards for antimicrobial susceptibility testing, 28th ed. CLSI supplement M100. Clinical and Laboratory Standards Institute, Wayne, PA

Crawford SD (2015) Lichens used in traditional medicine. In: Ranković B (ed) Lichen secondary metabolites: bioactive properties and pharmaceutical potential. Springer International Publishing, Cham, pp 27-80

Damman C (2013) Salicylates and the microbiota: a new mechanistic understanding of an ancient drug's role in dermatological and gastrointestinal disease. Drug Dev Res. https://doi.org/10.1002/ ddr. 21086

De Carvalho EAB, Andrade PP, Silva NH et al (2005) Effect of usnic acid from the lichen Cladonia substellata on Trypanosoma cruzi in vitro: an ultrastructural study. Micron 36:155-161. https:// doi.org/10.1016/j.micron.2004.09.003

Derici MK, Cansaran-Duman D, Taylan-Özkan A (2018) Usnic acid causes apoptotic-like death in Leishmania major, L. infantum and L. tropica. 3 Biotech 8:384. https://doi.org/10.1007/ s13205-018-1409-6

Durand GA, Raoult D, Dubourg G (2019) Antibiotic discovery: history, methods and perspectives. Int J Antimicrob Agents 53:371-382. https://doi.org/10.1016/j.ijantimicag.2018.11.010

EUCAST (2019) The European Committee on Antimicrobial Susceptibility Testing. Routine and extended internal quality control for MIC determination and disk diffusion as recommended by EUCAST. Version 9.0, 2019. http://www.eucast.org

EUCAST (2020) The European Committee on Antimicrobial Susceptibility Testing. Routine and extended internal quality control for MIC determination and agar dilution for yeasts and moulds as recommended by EUCAST Version 4.0, 2020. http://www. eucast.org

Fernández-Moriano C, Divakar PK, Crespo A, Gómez-Serranillos MP (2017) Protective effects of lichen metabolites evernic and usnic acids against redox impairment-mediated cytotoxicity in central nervous system-like cells. Food Chem Toxicol 105:262277. https://doi.org/10.1016/j.fct.2017.04.030

Fournet A, Ferreira ME, Rojas de Arias A et al (1997) Activity of compounds isolated from Chilean lichens against experimental cutaneous leishmaniasis. Comp Biochem Physiol Part C Pharmacol Toxicol Endocrinol 116:51-54. https://doi.org/10.1016/ s0742-8413(96)00127-2

Francolini I, Norris P, Piozzi A et al (2004) Usnic acid, a natural antimicrobial agent able to inhibit bacterial biofilm formation on polymer surfaces. Antimicrob Agents Chemother 48:4360 4365. https://doi.org/10.1128/AAC.48.11.4360

Francolini I, Piozzi A, Donelli G (2019) Usnic acid: potential role in management of wound infections. In: Donelli G (ed) Advances in microbiology, infectious diseases and public health, vol 13. Springer International Publishing, Cham, pp 31-41

Fritis MC, Lagos CR, Sobarzo NQ et al (2013) Depsides and triterpenes in Pseudocyphellaria coriifolia (lichens) and biological activity against Trypanosoma cruzi. Nat Prod Res 27:16071610. https://doi.org/10.1080/14786419.2012.740033

Garcia-Mateos RSM-CE-MS-HE-MP-TE-M del R (2017) Phenolic antioxidant capacity: a review of the state of the art. IntechOpen, Rijeka, p Ch. 4

Garcia Rowe J, Garcia Gimenez MD, Saenz Rodriguez MT (1999) Some lichen products have antimicrobial activity. Z Naturforsch C 54:605-609. https://doi.org/10.1515/znc-1999-7-824

Gökalsın B, Sesal NC (2016) Lichen secondary metabolite evernic acid as potential quorum sensing inhibitor against Pseudomonas aeruginosa. World J Microbiol Biotechnol 32:150. https://doi. org/10.1007/s11274-016-2105-5

Golubkova NS, Dombrovskaja MP, Zhurbenko MP et al (1996) Handbook of the lichens of Russia: part 6, Alectoriaceae, Parmeliaceae, Stereocaulaceae. Nauka, Saint Petersburg

Guha R, Van Drie JH (2008) Structure-activity landscape index: identifying and quantifying activity Cliffs. J Chem Inf Model 48:646-658. https://doi.org/10.1021/ci7004093

Guo L, Shi Q, Fang JL et al (2008) Review of usnic acid and Usnea barbata toxicity. J Environ Sci Heal Part C Environ Carcinog Ecotoxicol Rev 26:317-338. https://doi.org/10.1080/10590500802533392

Gupta VK, Verma S, Gupta S et al (2012) Membrane-damaging potential of natural L-(-)-usnic acid in Staphylococcus aureus. Eur J Clin Microbiol Infect Dis 31:3375-3383. https://doi.org/10.1007/ s10096-012-1706-7

Han D, Matsumaru K, Rettori D, Kaplowitz N (2004) Usnic acidinduced necrosis of cultured mouse hepatocytes: inhibition of mitochondrial function and oxidative stress. Biochem Pharmacol 67:439-451. https://doi.org/10.1016/j.bcp.2003.09.032

Hawrył A, Hawrył M, Hajnos-Stolarz A et al (2020) HPLC fingerprint analysis with the antioxidant and cytotoxic activities of selected lichens combined with the chemometric calculations. Molecules. https://doi.org/10.3390/molecules25184301

Hooper DC, Jacoby GA (2016) Topoisomerase inhibitors: fluoroquinolone mechanisms of action and resistance. Cold Spring Harb Perspect Med. https://doi.org/10.1101/cshperspect.a025320

Hsu L-M, Huang Y-S, Chang F-Y, Lee S-D (2005) "Fat burner" herb, usnic acid, induced acute hepatitis in a family. J Gastroenterol Hepatol 20:1138-1139

Huneck S, Yoshimura I (eds) (1996) Identification of lichen substances. Springer, Berlin, Heidelberg, pp 11-123 
Hutchings MI, Truman AW, Wilkinson B (2019) Antibiotics: past, present and future. Curr Opin Microbiol 51:72-80. https://doi.org/ 10.1016/j.mib.2019.10.008

Ingólfsdóttir K (2002) Usnic acid. Phytochemistry 61:729-736. https:// doi.org/10.1016/S0031-9422(02)00383-7

Joulain D, Tabacchi R (2009) Lichen extracts as raw materials in perfumery. Part 1: oakmoss. Flavour Fragr J 24:49-61. https://doi. org/10.1002/ffj. 1916

Karlov DS, Sosnin S, Tetko IV, Fedorov MV (2019) Chemical space exploration guided by deep neural networks. RSC Adv 9:51515157. https://doi.org/10.1039/C8RA10182E

Kemnic TR, Coleman M (2021) Trimethoprim sulfamethoxazole. In: StatPearls. StatPearls Publishing, Treasure Island (FL). December 11, 2020

Kohlhardt-Floehr C, Boehm F, Troppens S et al (2010) Prooxidant and antioxidant behaviour of usnic acid from lichens under UVBlight irradiation-studies on human cells. J Photochem Photobiol B 101:97-102. https://doi.org/10.1016/j.jphotobiol.2010.06.017

Kosanić M, Manojlović N, Janković S et al (2013) Evernia prunastri and Pseudoevernia furfuraceae lichens and their major metabolites as antioxidant, antimicrobial and anticancer agents. Food Chem Toxicol 53:112-118. https://doi.org/10.1016/j.fct.2012. 11.034

Lauinger IL, Vivas L, Perozzo R et al (2013) Potential of lichen secondary metabolites against Plasmodium liver stage parasites with FAS-II as the potential target. J Nat Prod 76:1064-1070. https:// doi.org/10.1021/np400083k

Luz JSB, De Oliveira EB, Martins MCB et al (2015) Ultrastructural analysis of Leishmania infantum chagasi promastigotes forms treated in vitro with usnic acid. Sci World J. https://doi.org/10. $1155 / 2015 / 617401$

Luzina OA, Salakhutdinov NF (2018) Usnic acid and its derivatives for pharmaceutical use: a patent review (2000-2017). Expert Opin Ther Pat 28:477-491. https://doi.org/10.1080/13543776. 2018.1472239

Maciąg-Dorszyńska M, Węgrzyn G, Guzow-Krzemińska B (2014) Antibacterial activity of lichen secondary metabolite usnic acid is primarily caused by inhibition of RNA and DNA synthesis. FEMS Microbiol Lett 353:57-62. https://doi.org/10.1111/15746968.12409

Manojlovic N, Rankovic B, Kosanic M et al (2012) Chemical composition of three Parmelia lichens and antioxidant, antimicrobial and cytotoxic activities of some their major metabolites. Phytomedicine 19:1166-1172. https://doi.org/10.1016/j.phymed.2012.07. 012

Millot M, Girardot M, Dutreix L et al (2017) Antifungal and anti-biofilm activities of acetone lichen extracts against Candida albicans. Molecules 22:651. https://doi.org/10.3390/molecules22040651

Mitrovic T, Stamenkovic S, Cvetkovic V et al (2011) Lichens as source of versatile bioactive compounds. Biol Nyssana 2:1-6

Mitrović T, Stamenković S, Cvetković V et al (2011) Antioxidant, antimicrobial and antiproliferative activities of five lichen species. Int J Mol Sci 12:5428-5448. https://doi.org/10.3390/ijms12085428

Mohammed HHH, Abuo-Rahma GE-DAA, Abbas SH, Abdelhafez E-SMN (2019) Current trends and future directions of fluoroquinolones. Curr Med Chem 26:3132-3149. https://doi.org/10.2174/ 0929867325666180214122944

Mowitz M, Zimerson E, Svedman C, Bruze M (2013) Patch testing with serial dilutions and thin-layer chromatograms of oak moss absolutes containing high and low levels of atranol and chloroatranol. Contact Dermat. https://doi.org/10.1111/cod.12126

Narui T, Sawada K, Takatsuki S et al (1998) NMR assignments of depsides and tridepsides of the lichen family umbilicariaceae. Phytochemistry 48:815-822. https://doi.org/10.1016/S00319422(97)00958-8
Neff GW, Reddy KR, Durazo FA et al (2004) Severe hepatotoxicity associated with the use of weight loss diet supplements containing ma huang or usnic acid. J Hepatol 41:1062-1064

Nguyen K (2013) UV-protectant metabolites from lichens and their symbiotic partners. Nat Prod Rep. https://doi.org/10.1039/c3np7 $0064 \mathrm{j}$

Nithyanand P, Beema Shafreen RM, Muthamil S, Karutha Pandian S (2015) Usnic acid inhibits biofilm formation and virulent morphological traits of Candida albicans. Microbiol Res 179:20-28. https://doi.org/10.1016/j.micres.2015.06.009

Pastrana-Mena R, Mathias DK, Delves M et al (2016) A malaria transmission-blocking (+)-usnic acid derivative prevents Plasmodium zygote-to-ookinete maturation in the mosquito midgut. ACS Chem Biol 11:3461-3472. https://doi.org/10.1021/acsch embio.6b00902

Peralta MA, da Silva MA, Ortega MG et al (2017) Usnic acid activity on oxidative and nitrosative stress of azole-resistant Candida albicans biofilm. Planta Med 83:326-333. https://doi.org/10. 1055/s-0042-116442

Piorkowski G (1957) Usnic acid as an oral antivirotic. Ther Ggw 96:286-287

Pires RH, Lucarini R, Mendes-Giannini MJS (2012) Effect of usnic acid on Candida orthopsilosis and C. parapsilosis. Antimicrob Agents Chemother 56:595-597. https://doi.org/10.1128/AAC. 05348-11

Pompilio A, Pomponio S, Di Vincenzo V et al (2013) Antimicrobial and antibiofilm activity of secondary metabolites of lichens against methicillin-resistant Staphylococcus aureus strains from cystic fibrosis patients. Future Microbiol 8:281-292. https://doi. org/10.2217/fmb. 12.142

Pompilio A, Riviello A, Crocetta V et al (2016) Evaluation of antibacterial and antibiofilm mechanisms by usnic acid against methicillin-resistant Staphylococcus aureus. Future Microbiol 11:1315-1338. https://doi.org/10.2217/fmb-2016-0049

Pramyothin P, Janthasoot W, Pongnimitprasert N et al (2004) Hepatotoxic effect of (+)usnic acid from Usnea siamensis Wainio in rats, isolated rat hepatocytes and isolated rat liver mitochondria. $\mathbf{J}$ Ethnopharmacol 90:381-387. https://doi.org/10.1016/j.jep.2003. 10.019

Proksa B, Šturdíková M, Prónayová N, Liptaj T (1996) (-)-Usnic acid and its derivatives. their inhibition of fungal growth and enzyme activity. Pharmazie 51:195-196

Ranković B, Kosanić M (2015) Lichens as a potential source of bioactive secondary metabolites. In: Ranković B (ed) Lichen secondary metabolites: bioactive properties and pharmaceutical potential. Springer International Publishing, Cham, pp 1-26

Sander T, Freyss J, von Korff M, Rufener C (2015) DataWarrior: an open-source program for chemistry aware data visualization and analysis. J Chem Inf Model 55:460-473. https://doi.org/10.1021/ ci500588j

Schmeda-Hirschmann G, Tapia A, Lima B et al (2008) A new antifungal and antiprotozoal depside from the andean lichen Protousnea poeppigii. Phytother Res 22:349-355. https://doi.org/10.1002/ptr. 2321

Sepahvand A, Studzińska-Sroka E, Ramak P, Karimian V (2021) Usnea sp.: antimicrobial potential, bioactive compounds, ethnopharmacological uses and other pharmacological properties; a review article. J Ethnopharmacol 268:113656. https://doi.org/10.1016/j. jep.2020.113656

Shrestha G, Clair LLS (2013) Lichens: a promising source of antibiotic and anticancer drugs. Phytochem Rev 12:229-244. https://doi.org/ 10.1007/s11101-013-9283-7

Si K, Wei L, Yu X et al (2016) Effects of (+)-usnic acid and (+)-usnic acid-liposome on Toxoplasma gondii. Exp Parasitol 166:68-74. https://doi.org/10.1016/j.exppara.2016.03.021 
Sinha S, Gupta VK, Kumar P et al (2019) Usnic acid modifies MRSA drug resistance through down-regulation of proteins involved in peptidoglycan and fatty acid biosynthesis. FEBS Open Bio 9:2025-2040. https://doi.org/10.1002/2211-5463.12650

Sokolov DN, Zarubaev VV, Shtro AA et al (2012) Anti-viral activity of (-) - and (+) -usnic acids and their derivatives against influenza virus A (H1N1) 2009. Bioorg Med Chem Lett 22:7060-7064. https://doi.org/10.1016/j.bmcl.2012.09.084

Staples R, LaDuca RL, Roze LV et al (2020) Structure and chemical analysis of major specialized metabolites produced by the lichen Evernia prunastri. Chem Biodivers 17:e1900465. https://doi.org/ 10.1002/cbdv.201900465

Stocker-Wörgötter E, Cordeiro LMC, Iacomini M (2013) Chapter 10_ Accumulation of potential pharmaceutically relevant lichen metabolites in lichens and cultured lichen symbionts. In: Chemistry A-RBT-S in NP (ed) Studies in natural products chemistry. Elsevier, Amsterdam, pp 337-380

Strömstedt AA, Park S, Burman R, Göransson U (2017) Bactericidal activity of cyclotides where phosphatidylethanolamine-lipid selectivity determines antimicrobial spectra. Biochimica et Biophysica Acta (BBA) - Biomembranes 1859(10):1986-2000. https://doi. org/10.1016/j.bbamem.2017.06.018

Studzinska-Sroka E, Galanty A, Bylka W (2017) Atranorin-an interesting lichen secondary metabolite. Mini Rev Med Chem 17:1633-1645

Tapalsky DV, Petrenev DR, Khramchenkova OM, Doroshkevich AS (2017) Antimicrobial and antifungal activity of lichens prevalent in Belarus. Zhurnal Mikrobiol Epidemiol i Immunobiol 2:60-65

Tozatti MG, Ferreira DS, Flauzino LGB et al (2016) Activity of the lichen Usnea steineri and its major metabolites against Grampositive, multidrug-resistant bacteria. Nat Prod Commun 11:1934578X1601100419. https://doi.org/10.1177/1934578X16 01100419

Uter W, Johansen JD, Börje A et al (2013) Categorization of fragrance contact allergens for prioritization of preventive measures: clinical and experimental data and consideration of structure-activity relationships. Contact Dermat 69:196-230. https://doi.org/10. $1111 / \operatorname{cod} .12117$

Van Der Maaten L (2014) Accelerating T-SNE using tree-based algorithms. J Mach Learn Res 15:3221-3245

Victor K, Boris L, Athina G et al (2018) Design, synthesis and antimicrobial activity of usnic acid derivatives. MedChemComm 9:870-882. https://doi.org/10.1039/C8MD00076J
Vijayakumar CS, Viswanathan S, Reddy MK et al (2000) Anti-inflammatory activity of (+)-usnic acid. Fitoterapia 71:564-566. https:// doi.org/10.1016/s0367-326x(00)00209-4

von Korff M, Sander T (2006) Toxicity-indicating structural patterns. J Chem Inf Model 46:536-544. https://doi.org/10.1021/ci050358k

Wang X-P, Liu H-J, Zhen L et al (2006) Plasmid elimination effect of usnic acid on antibiotic-resistant Staphylococcus aureus. Zhong Yao Cai 29:36-39

Wei AH, Zhou DN, Ruan JL et al (2012) Characterisation of phenols and antioxidant and hypolipidaemic activities of Lethariella cladonioides. J Sci Food Agric 92:373-379. https://doi.org/10.1002/ jsfa.4601

White PA, Oliveira RC, Oliveira AP et al (2014) Antioxidant activity and mechanisms of action of natural compounds isolated from lichens: a systematic review. Molecules 19:14496-14527. https:// doi.org/10.3390/molecules 190914496

WHO (2020) Antibiotic resistance. World Health Organization. https:// www.who.int/news-room/fact-sheets/detail/antibiotic-resistance. Accessed 31 Mar 2021

Wiegand I, Hilpert K, Hancock REW (2008) Agar and broth dilution methods to determine the minimal inhibitory concentration (MIC) of antimicrobial substances. Nat Protoc 3:163-175. https://doi. org/10.1038/nprot.2007.521

Wirth V, Anderegg D (1995) The lichens: Baden-Württemberg. Ulmer

Yamamoto Y, Miura Y, Kinoshita Y et al (1995) Screening of tissue cultures and thalli of lichens and some of their active constituents for inhibition of tumor promoter-induced Epstein-Barr virus activation. Chem Pharm Bull (Tokyo) 43:1388-1390. https://doi.org/ $10.1248 / \mathrm{cpb} .43 .1388$

Yilmaz M, Turk AO, Tay T, Kivanc M (2004) The antimicrobial activity of extracts of the lichen Cladonia foliacea and its (-) -usnic acid, atranorin, and fumarprotocetraric acid constituents. Zeitschrift Fur Naturforsch 59:249-254

Zambare VP, Christopher LP (2012) Biopharmaceutical potential of lichens. Pharm Biol 50:778-798. https://doi.org/10.3109/13880 209.2011.633089

Publisher's Note Springer Nature remains neutral with regard to jurisdictional claims in published maps and institutional affiliations. 